\title{
Screening of Maize Rhizosperic Phosphate Solubilizing Isolates for Plant Growth Promoting Characteristics
}

\author{
S. Vinod Babu ${ }^{*}$, S. Triveni ${ }^{1}$, R. Subhash Reddy ${ }^{1}$ and J. Sathyanarayana ${ }^{2}$ \\ ${ }^{1}$ Department of Agricultural Microbiology and Bioenergy, College of Agriculture, Professor \\ Jayashankar Telangana State Agriculture University (PJTSAU), Rajendranagar, \\ Hyderabad, Telangana, India \\ ${ }^{2}$ Department of Entomology, College of Agriculture, PJTSAU, Rajendranagar, \\ Hyderabad, Telangana, India \\ *Corresponding author
}

\begin{tabular}{|c|c|}
\hline & A B S T R A C T \\
\hline & \multirow{6}{*}{$\begin{array}{l}\text { Maize forms a major part of cereal crops consumed by man and serve as a source of } \\
\text { dietary carbohydrates. It is used for livestock feed and it is the cheapest and palatable } \\
\text { livestock feed for animals such as pig, cattle, sheep, poultry and it is also a source of raw } \\
\text { materials for the production of corn sugar, corn starch, corn syrup and corn oil. In the } \\
\text { present study twenty four (24) phosphate solubilizing bacteria (i.e., sixteen Bacillus and } \\
\text { eight Pseudomonas) isolated from Maize research station and college farm, Rajendranagar, } \\
\text { PJTSAU, Telangana and characterised by their Plant Growth Promoting Properties } \\
\text { (PGPR) under in vitro conditions such as P, Zn and K solubilization. The isolate PSB } 6 \\
\text { showed maximum Phosphate solubilization zone of } 15.50 \mathrm{~mm} \text { and the solubilization } \\
\text { efficiency ( } \% \text { ) is } 258.33 \% \text {. The isolates both PSB } 6 \text { and PSB } 19 \text { showed maximum Zinc } \\
\text { solubilization zone i.e., } 14.00 \mathrm{~mm} \text { and the solubilization efficiency (\%) maximum for PSB } \\
6 \text { i.e., } 233.30 \% \text {. The isolate PSB } 11 \text { showed maximum Potassium solubilization zone of } \\
14.00 \text { mm with the solubilization efficiency (\%) of } 280.00 \% \text {. Apart from these all (24) } \\
\text { isolates were screened for IAA production, exopolysacharide production, siderophore } \\
\text { production and HCN production also. All the isolates responded positively to the IAA } \\
\text { production except PSB 5, PSB } 15 \text { and PSB } 22 \text { were negative. All the isolates (24) were } \\
\text { positive to the exopolysacharide production except PSB } 10 \text { and PSB } 17 \text {. All the isolates } \\
\text { (24) were positive to the siderophore production except PSB 2, PSB 9, PSB } 13 \text { and PSB } \\
19 \text {. All the isolates (24) were positive to the HCN production except PSB } 11 \text {, PSB } 17 \text { and } \\
\text { PSB } 24 \text {. }\end{array}$} \\
\hline Keywords & \\
\hline $\begin{array}{l}\text { Cereal crops, } \\
\text { Maize, } \\
\text { Carbohydrates, } \\
\text { Pseudomonas. }\end{array}$ & \\
\hline Article Info & \\
\hline $\begin{array}{l}\text { Accepted: } \\
17 \text { August } 2017 \\
\text { Available Online: } \\
10 \text { October } 2017\end{array}$ & \\
\hline & \\
\hline
\end{tabular}

\section{Introduction}

Among the crops corn (Zea mays) is an important in temperate climatic region because of the increasing demand for food and livestock feed. Nitrogen and phosphorus are essential nutrients for plant growth and development in corn (Wua et al., 2005). The phosphorus is mostly insoluble form in the soil and it is unavailable to plants. Nitrogen fixing and $\mathrm{P}$ solubilizing bacteria are important for plant nutrition by increasing $\mathrm{N}$ and $\mathrm{P}$ uptake by the plants and playing a significant role as a Plant Growth Promoting Rhizobacteria (PGPR). Nitrogen fixation and $\mathrm{P}$ solubilization (Zaidi et al., 2006) 
production of antibiotics (Zahir et al., 2004) are the principal mechanism for the PGPR.

In the context of increasing international concern for food and environmental quality, the use of PGPR for reducing chemical inputs in agriculture is a potentially important issue.

PGPR are applied to various crops to enhance growth, seed emergence and crop yield and some commercialized.

PGPRs are the potential tools for sustainable agriculture and trend for the future. The present investigation continued on mainly collection of phosphate solubilizing microorganisms from different maize rhizospheric soils and commercial PSB inoculants. Preparing the different types (carrier, liquid and biofilmed) of biofertilizer formulations and test the efficacy and persistence of biofilmed based PSB and other types of biofertilizers with Maize crop.

Beneficial biofilms developed by nitrogen fixing bacteria and $\mathrm{P}$ - solubilising fungi in vitro conditions and also used as biofertilizers in non - leguminous crops and also observed that the bacteria colonized fungal mycelia to form biofilms. The biofilms showed high rates of biological nitrogen fixation and organic acid production which directly influences the synthesis of indole acetic acid like substances than microbes when used as monocultures. (Seneiviratne et al., 2003)

\section{Materials and Methods}

\section{Soil sample collection and Isolation}

Samples were collected from Maize Research Station, Hyderabad and College Farm, College of Agriculture, Rajendranagar, Hyderabad. For the isolation of Phosphate solubilizing bacteria Pikovaskya's medium was used.
Morphological characterization of phosphate solubilizing bacterial isolates

All the Phosphate solubilizing bacterial isolates were checked for their purity and then studied for the colony morphology and pigmentation. The cell shape and gram reaction was also recorded as per the standard procedures given by Barthalomew and Mittewar (1950).

\section{Screening of PSB isolates for Plant Growth Promoting (PGP) properties}

Pure isolates were isolated by streaking isolates on respective media and screened for following Plant growth promoting characteristics viz. production of IAA, siderophores, $\mathrm{HCN}$ and their ability to solublize phosphorous.

\section{Phosphate solubilization}

Sterilized Pikovskaya's agar was poured as a thin layer on to the sterilized petriplates and incubated for $24 \mathrm{~h}$. After incubation the Pikovskaya's plates were spot inoculated with isolates and incubated at $28 \pm 1{ }^{\circ} \mathrm{C}$ for $4-5$ days. Formation of a clear zone around the colonies was considered as positive result for phosphate solubilization.

PSE (Phosphate Solubilization Efficiency) = $\mathrm{Z} / \mathrm{C} \times 100$

Z - Clearance zone including bacterial growth

C - Colony diameter

\section{Zinc solubilization}

The isolates were inoculated into agar medium containing $0.1 \%$ insoluble zinc compounds viz $\mathrm{ZnO}, \quad \mathrm{ZnS}$ and $\mathrm{ZnCO}_{3}$ (Saravanan et al., 2013).Formation of a clear zone around the colonies were considered as 
positive result for zinc solubilization. The diameters of the clearing zones around the colonies are measured.

\section{Potassium Solubilization}

Bacterial colonies exhibiting clear zone of potassium solubilization on Aleksandrov agar were selected as potassium solubilizers. Secondary screening was carried out on the basis of study of zone activity of the different isolates by using Khandeparkar's selection ratio (Prajapati and Modi, 2012). The diameter of the clearing zone around the colonies were measured.

\section{Exo polysaccharide production (EPS)}

Initially prepare TSP broth with $-0.30 \mathrm{Mpa}$ osmotic stress with 15\% PEG 6000. Inoculated TSP broth with test culture incubate for 3 days. After incubation culture was centrifuged at $20,000 \mathrm{~g}$ in refrigerated centrifuge for $25 \mathrm{~min}$. Collect the supernatant and filtrate supernatant $0.45 \mu \mathrm{m}$ nitro cellulose membrane. These filtrate dialysed against $4^{\circ} \mathrm{C}$. The dialysed again centrifuged at $20,000 \mathrm{~g}$ for $25 \mathrm{~min}$ remove any insoluble material and mixed with 3 volumes ice cold absolute alcohol and kept overnight at $4^{\circ} \mathrm{C}$. Precipitated EPS obtained by centrifugation at $10,000 \mathrm{~g}$ for $15 \mathrm{~min}$. Suspended in water purification of EPS (Sandhya et al., 2009).

\section{Indole acetic acid production}

Indole Acetic acid Production was tested according to Gorden and Weber (1951).The active culture of each test isolate was raised in $5 \mathrm{ml}$ respective broth tubes and incubated at determined temperature and time. After incubation these cultures were centrifuged at recommended rpm and time. Two drops of Orthophosphoric acid was added to $2 \mathrm{ml}$ of supernatant and incubated for $30 \mathrm{~min}$ to develop the colour. Development of pink colour considered as positive for IAA production.

\section{Protein estimation}

One $\mathrm{ml}$ of the sample was taken and cells were pelleted by centrifugation at $10,000 \mathrm{rpm}$ for $8 \mathrm{~min}$. Spectrophotometric measurement of colour development was done by using the method of Lowry et al., (1951). Intensity of blue colour was measured at absorbance maximum of $660 \mathrm{~nm}$.

\section{Siderophore production}

Siderophore production was estimated qualitatively. Chrome Azurol S (CAS) Agar medium (Schwyn and Neilands, 1987). For the detection of siderophores, each isolate was grown in synthetic medium, containing 0.5 $\mu \mathrm{M}$ of iron and incubated for $24 \mathrm{~h}$ on a rotary shaker at room temperature. Chrome Azurol S (CAS) assay was used to detect the siderophores. The CAS plates were used to check the culture supernatant for the presence of siderophores. Culture supernatant was added to the wells made on the CAS agar plates and incubated at room temperature for $24 \mathrm{~h}$. Formation of yellow to orange coloured zone around the well indicated the siderophore production.

\section{Hydrogen Cyanide Production (HCN)}

The HCN production was tested by the method of Castric and Castric (1983). First respective media added with glycine plates were prepared separately and incubated for 24 h. After that, $1 \mathrm{ml}$ of culture of each test isolate was inoculated on respective media plates separately. A disc of whatman filter paper No.1 of the diameter equal to the petri plate size, impregnated with alkaline picric acid solution $(0.5 \%$ picric acid (w/v) in $1 \%$ sodium carbonate) was placed in the upper lid of the inoculated petri plates under aseptic 
condition. The control plate did not receive the inoculum. The plates were incubated upside down at $28 \pm 2{ }^{\circ} \mathrm{C}$ for $48-72 \mathrm{~h}$. Change the colour from yellow to light brown, moderate or strong reddish brown was taken as indication of $\mathrm{HCN}$ production.

\section{Broth assay}

\section{In vitro biosolubilization of rock phosphate}

Phosphate solubilization potential of Phospahte solubilizing microbes were studied in vitro by estimation of available phosphorus in Pikovskaya's broth medium with known amount of Tri-calcium phosphate $(0.5 \mathrm{~g} 100$ $\mathrm{ml}^{-1}$ ) as a substrate before sterilization. Each of $5 \mathrm{~mm}$ mycelial bit of test fungal culture and $0.5 \mathrm{ml}$ suspension of each bacterial culture was inoculated in $250 \mathrm{ml}$ conical flask containing $100 \mathrm{ml}$ sterilized Pikovskaya's broth medium and make triplicate (biofilm preparation). A control without any PSM was also maintained. The fungal and bacterial isolates were allowed to grow for seven and fourteen days at $28 \pm 2^{0} \mathrm{C}$ in BOD incubator. To know the bios olubilisation of rock phosphate by biofilms, broth was filtered through whatman filter paper No. 42 and centrifuged at $15,000 \mathrm{rpm}$ for $30 \mathrm{~min}$ in centrifugation. The clear supernatant was collected in $100 \mathrm{ml}$ volumetric flasks and volume was made up to $100 \mathrm{ml}$ with sterilized distilled water. Thus extract of each test biofilm solution was prepared then the available phosphorus in broth culture was determined (Gaur, 1990).

\section{Results and Discussion}

Four soil samples were collected from Maize Research Station, Hyderabad and College Farm, College of Agriculture, Rajendranagar, Hyderabad. Twenty four (24) phosphate solubilizing bacteria (i.e., sixteen Bacillus and eight Pseudomonas) isolates collected and screen their plant growth promoting characters.

Screening of isolates for their Plant Growth Promoting (PGP) characters

\section{Phosphate Solubilization}

\section{Qualitative method}

All the sixteen Bacillus isolates were able to form clear zone of phosphate solubilization on Pikovaskaya'sagar plate ranged from 15.50- $6.10 \mathrm{~mm}$. Among them PSB 6 of Bacillus spp detected the highest solubilization zone $(15.50 \mathrm{~mm})$ followed by PSB $5(14.80 \mathrm{~mm})$ and the lowest solubilization zone was observed with PSB 3 $(6.10 \mathrm{~mm})$.

All the eight Pseudomonas isolates were able to form clear zone of phosphate solubilization on Pikovaskaya'sagar plate ranged from 12.00 - $6.40 \mathrm{~mm}$. Among them PSB 24 of Pseudomonas spp detected as highest solubilization zone $12.00 \mathrm{~mm}$ followed by PSB $20(11.00 \mathrm{~mm})$ and the lowest solubilization was showed by PSB 22 (6.40 $\mathrm{mm}$ ). The Aspergillus spp (Asp1) showed $10.1 \mathrm{~mm}$ Phosphate solubilization zone. (Table 1 and Plate 1) Bacillus and Pseudomonas spp differ in the ability to produce phosphatase enzyme and production of organic acids and hence showed different solubilization efficiency.

Tensingh et al., (2015) identified the selected strains were Bacillus and Pseudomonas. The isolated strains were characterized under in vitro conditions. They showed solubilization zone ranges from $2-5 \mathrm{~mm}$ at $28-30^{\circ} \mathrm{C}$. The highest solubilization was observed with Pseudomonas putida $(5 \mathrm{~mm})$ followed by $P$. flourescens (4 $\mathrm{mm})$ and the lowest solubilization was observed in Bacillus megaterium (2 $\mathrm{mm})$. Similarly Uma and 
Sathiyavani (2012) reported phosphate solubilization by Bacillus spp from groundnut rhizosphere (Arachishypogaea L).

Quantitative estimation of available phosphorus in Pikovaskaya's broth

All the sixteen Bacillus isolates were able to solubilize the available phosphorus in Pikovaskaya's broth with known amount of Tri - calcium phosphate as a substrate. Among them PSB 6 recorded the more available phosphorus content of $0.89 \mathrm{mg} \mathrm{L}^{-}$ ${ }^{1}(\mathrm{pH}:$ 7.10). Second best was showed by different isolates PSB 8 and PSB 10 i.e., 0.82 $\mathrm{mg} \mathrm{L}^{-1}(\mathrm{pH}$ : 7.00and 6.00). The lowest was shown by PSB 16 with $0.57 \mathrm{mg} \mathrm{L}^{-1}$ (pH: 7.89).

All the eight Pseudomonas isolates were able to solubilize the available phosphorus in Pikovaskaya's broth with known amount of Tri - calcium phosphate as a substrate. Among them PSB 24was recorded the highest available phosphorus content of $0.82 \mathrm{mg} \mathrm{L}$ ${ }^{1}$ (pH: 7.00). Second best was observed by the isolate PSB 18 and PSB 23 i.e., $0.81 \mathrm{mg} \mathrm{L}^{-}$ ${ }^{1}(\mathrm{pH}: \quad 6.80$ and 7.00$)$. The lowest was recorded by PSB 21 with $0.54 \mathrm{mg} \mathrm{L}^{-1}(\mathrm{pH}$ : 6.00) phosphorus solublization. The Aspergillus spp (Asp1) showed available phosphorus concentration i.e., $0.78 \mathrm{mg} \mathrm{L}$ (pH: 6.70) respectively (Table 1 ).

Similar results were observed by Karpagam and Nagalakshmi. (2014) i.e., thirty seven Phosphate solubilizing microbial isolates were isolated on the Pikovskaya's agar medium. Out of 37 microbial isolates eight isolates were showed highest Phosphate Solubilization Index (PSI) ranged from 1.13 $3.00 \mathrm{mg} \mathrm{L}^{-1}$ and they were selected for the qualitative as well as quantitative study. Among these eight potent isolates, 3 strains (PSM 1, PSM 2 and PSM6) showed maximum PSI on agar plates along with high soluble phosphate production of $0.37 \mathrm{mg} \mathrm{L}^{-1}$,
$0.30 \mathrm{mg} \mathrm{L}^{-1}$ and $0.28 \mathrm{mg} \mathrm{L}^{-1}$ in Pikovaskaya's broth.

\section{Zinc solubilization}

Among sixteen Bacillus isolates, thirteen were positive for zinc solubilization on Tris minimal media supplemented with zinc oxide and ranged from 14.00- $6.40 \mathrm{~mm}$. Among them PSB 6 of Bacillus spp recorded the highest solubilization zone $(14 \mathrm{~mm})$ followed by PSB $8(13.00 \mathrm{~mm})$ and the lowest solubilization was observed in PSB 2 (6.40 $\mathrm{mm})$. The zinc solubilization was negative in the isolates PSB 7, PSB 9 and PSB 12.

Among eight Pseudomonas isolates, seven isolates recorded to be positive for zinc solubilization on Tris - minimal media supplemented with Zinc oxide and ranged from $14.00-8.70 \mathrm{~mm}$. Among them PSB 19 of Pseudomonas isolate recorded the highest solubilization zone $(14.00 \mathrm{~mm})$. Second best was shown by PSB $21(12.00 \mathrm{~mm})$. The lowest was shown by PSB $24(8.70 \mathrm{~mm})$. No solubilization was recorded in the isolate PSB 20 whereas fungal isolate Aspergillus spp (Asp1) showed $10.00 \mathrm{~mm}$ zinc solubilization zone. (Table 1 and Plate 1) Similar results were observed by Goteti et al., (2013) who screened ten strains for zinc solubilization among which P29, P33, and B40 produced $22.0 \mathrm{~mm}$ clear halos on solid medium amended with zinc carbonate. Similarly P17 and B40 showed $31.0 \mathrm{~mm}$ zone in zinc oxide incorporated medium.

\section{Potassium solubilization}

Among sixteen Bacillus isolates, fourteen isolates were able to form clear zone of potassium solubilization on modified Aleksandrov media ranged from $14.00-8.00$ $\mathrm{mm}$. Among them PSB 11 isolate recorded the highest solubilization zone $(14.00 \mathrm{~mm})$, followed by PSB $12(13.90 \mathrm{~mm})$. 
Table.1 Phosphorus, Zinc and Potassium solubilisation efficiency of different bacterial isolates

\begin{tabular}{|c|c|c|c|c|c|c|c|c|c|c|}
\hline \multirow[b]{2}{*}{$\begin{array}{c}\text { Isolate } \\
\text { Code }\end{array}$} & \multicolumn{2}{|c|}{ Zone diameter } & \multirow{2}{*}{$\begin{array}{l}\text { Phosphorus } \\
\text { Solubilization } \\
\text { efficiency }(\%)\end{array}$} & \multirow{2}{*}{$\begin{array}{c}\text { Soluble } \\
P \\
\text { concentr } \\
\text { ation } \\
\left(\mathrm{mg} \mathrm{L}^{-1}\right)\end{array}$} & \multirow{2}{*}{$\begin{array}{c}\text { Zinc } \\
\text { Solubilization } \\
\text { zone }(\mathbf{m m})\end{array}$} & \multirow{2}{*}{$\begin{array}{l}\text { Culture } \\
\text { diameter } \\
(\mathbf{m m})\end{array}$} & \multirow{2}{*}{$\begin{array}{c}\text { Zinc } \\
\text { Solubilization } \\
\text { efficiency }(\%)\end{array}$} & \multirow{2}{*}{$\begin{array}{l}\text { Potassium } \\
\text { Solubilization } \\
\text { zone }(\mathbf{m m})\end{array}$} & \multirow{2}{*}{$\begin{array}{l}\text { Culture } \\
\text { diameter } \\
(\mathbf{m m})\end{array}$} & \multirow{2}{*}{$\begin{array}{c}\text { Potassium } \\
\text { Solubilization } \\
\text { efficiency }(\%)\end{array}$} \\
\hline & $\begin{array}{c}\text { Solubilization } \\
\text { zone }(\mathbf{m m})\end{array}$ & $\begin{array}{c}\text { Culture } \\
\text { diameter } \\
(\mathbf{m m})\end{array}$ & & & & & & & & \\
\hline PSB1 & 9.10 & 5.00 & 182.00 & 0.63 & 12.20 & 8.00 & 152.50 & 9.30 & 6.00 & 155.00 \\
\hline PSB2 & 8.60 & 6.30 & 136.50 & 0.60 & 6.40 & 5.80 & 110.34 & 0.00 & 0.00 & 0.00 \\
\hline PSB3 & 6.10 & 5.20 & 117.30 & 0.62 & 7.80 & 5.90 & 132.20 & 8.00 & 6.30 & 126.98 \\
\hline PSB4 & 8.00 & 4.10 & 195.10 & 0.71 & 8.50 & 4.50 & 188.80 & 11.60 & 7.20 & 161.10 \\
\hline PSB5 & 14.80 & 6.00 & 246.60 & 0.79 & 9.50 & 6.00 & 158.33 & 13.50 & 7.30 & 184.90 \\
\hline PSB6 & 15.50 & 6.00 & 258.33 & 0.89 & 14.00 & 6.00 & 233.30 & 13.20 & 7.60 & 173.60 \\
\hline PSB7 & 12.30 & 8.00 & 153.75 & 0.76 & 0.00 & 0.00 & 0.00 & 8.60 & 6.00 & 143.30 \\
\hline PSB8 & 9.10 & 4.00 & 227.50 & 0.82 & 13.00 & 6.00 & 216.60 & 10.40 & 6.30 & 165.00 \\
\hline PSB9 & 6.60 & 4.00 & 165.00 & 0.68 & 0.00 & 0.00 & 0.00 & 0.00 & 0.00 & 0.00 \\
\hline PSB10 & 14.50 & 6.40 & 226.60 & 0.82 & 8.60 & 6.70 & 128.30 & 12.60 & 6.80 & 185.20 \\
\hline PSB11 & 10.40 & 6.40 & 162.50 & 0.75 & 10.30 & 8.40 & 123.80 & 14.00 & 5.00 & 280.00 \\
\hline PSB12 & 13.50 & 9.00 & 150.00 & 0.78 & 0.00 & 0.00 & 0.00 & 13.90 & 6.00 & 231.60 \\
\hline PSB14 & 12.00 & 10.00 & 120.00 & 0.77 & 12.50 & 6.00 & 208.33 & 12.70 & 7.90 & 160.70 \\
\hline PSB15 & 10.80 & 5.50 & 196.30 & 0.60 & 10.60 & 5.60 & 189.20 & 10.30 & 5.20 & 198.00 \\
\hline PSB16 & 11.40 & 5.70 & 200.00 & 0.57 & 8.00 & 4.10 & 195.10 & 11.60 & 5.00 & 232.00 \\
\hline PSB17 & 8.30 & 6.40 & 129.60 & 0.74 & 10.80 & 5.50 & 196.30 & 12.20 & 5.50 & 221.81 \\
\hline PSB18 & 9.70 & 6.00 & 161.60 & 0.81 & 11.00 & 5.40 & 203.70 & 9.40 & 5.70 & 164.90 \\
\hline PSB19 & 8.70 & 6.90 & 126.00 & 0.65 & 14.00 & 6.80 & 205.88 & 6.00 & 5.30 & 113.20 \\
\hline PSB20 & 11.00 & 9.20 & 119.50 & 0.65 & 0.00 & 0.00 & 0.00 & 9.80 & 4.50 & 217.70 \\
\hline PSB21 & 8.40 & 6.70 & 125.30 & 0.54 & 12.00 & 7.00 & 171.40 & 0.00 & 0.00 & 0.00 \\
\hline PSB22 & 6.40 & 5.60 & 114.28 & 0.77 & 9.00 & 7.00 & 128.50 & 9.70 & 7.00 & 137.10 \\
\hline PSB23 & 9.40 & 6.00 & 156.60 & 0.81 & 9.30 & 6.00 & 156.60 & 10.00 & 7.00 & 142.80 \\
\hline PSB24 & 12.00 & 6.00 & 200.00 & 0.82 & 8.70 & 7.00 & 124.28 & 0.00 & 0.00 & 0.00 \\
\hline Asp1 & 10.10 & 5.80 & 174.10 & 0.78 & 10.00 & 6.40 & 156.20 & 12.00 & 8.00 & 150.00 \\
\hline CD & 0.313 & & & 0.035 & 0.298 & & & 0.290 & & \\
\hline SE(d) & 0.155 & & & 0.018 & 0.147 & & & 0.143 & & \\
\hline $\mathrm{SE}(\mathrm{m})$ & 0.110 & & & 0.012 & 0.104 & & & 0.101 & & \\
\hline $\mathrm{CV}$ & 1.855 & & & 2.969 & 1.751 & & & 1.617 & & \\
\hline
\end{tabular}


Table.2 Evaluation of different isolates for their Plant Growth Promoting (PGP) characters

\begin{tabular}{|c|c|c|c|c|c|}
\hline $\begin{array}{l}\text { ISOLATE } \\
\text { CODE }\end{array}$ & $\begin{array}{c}\text { PROTEIN } \\
\text { ESTIMATION } \\
\left(\mathrm{mg} \mathrm{L}^{-1}\right)\end{array}$ & $\begin{array}{c}\text { IAA } \\
\text { PRODUCTION } \\
\left(\mu \mathrm{g} \mathrm{mL}^{-1}\right)\end{array}$ & $\begin{array}{c}\text { EXOPLOYSACHAR } \\
\text { IDE PRODUCTION } \\
\text { (EPS) }\end{array}$ & $\begin{array}{l}\text { SIDEROPHORE } \\
\text { PRODUCTION }\end{array}$ & $\begin{array}{c}\text { HCN } \\
\text { PRODUCTION }\end{array}$ \\
\hline PSB1 & 0.48 & 39.30 & + & ++ & ++ \\
\hline PSB2 & 0.30 & 41.50 & + & - & + \\
\hline PSB3 & 0.40 & 29.50 & +++ & ++ & ++ \\
\hline PSB4 & 0.44 & $\begin{array}{l}50.70 \\
\end{array}$ & + & + & + \\
\hline PSB5 & 0.43 & 0.00 & + & ++ & + \\
\hline PSB6 & 0.58 & 24.40 & ++ & +++ & ++ \\
\hline PSB7 & 0.46 & 33.50 & + & + & + \\
\hline PSB8 & 0.41 & 40.60 & + & + & + \\
\hline PSB9 & 0.43 & 29.90 & + & - & + \\
\hline PSB10 & 0.50 & 25.20 & - & ++ & +++ \\
\hline PSB11 & 0.30 & 39.80 & + & + & - \\
\hline PSB12 & 0.55 & 23.00 & + & + & ++ \\
\hline PSB13 & 0.42 & 31.50 & ++ & - & + \\
\hline PSB14 & 0.35 & 23.40 & + & ++ & ++ \\
\hline PSB15 & 0.39 & 0.00 & + & + & + \\
\hline PSB16 & 0.34 & 36.70 & + & + & ++ \\
\hline PSB17 & 0.43 & 32.50 & - & +++ & - \\
\hline PSB18 & 0.45 & 27.70 & + & + & + \\
\hline PSB19 & 0.49 & 31.90 & ++ & - & + \\
\hline PSB20 & 0.50 & 49.80 & +++ & ++ & +++ \\
\hline PSB21 & 0.37 & 28.90 & + & + & ++ \\
\hline PSB22 & 0.35 & 0.00 & ++ & +++ & + \\
\hline PSB23 & 0.38 & 29.40 & + & ++ & + \\
\hline PSB24 & 0.40 & 34.20 & +++ & + & - \\
\hline Asp1 & 0.32 & 36.00 & - & + & + \\
\hline CD & 0.017 & 0.252 & & & \\
\hline SE(d) & 0.009 & 0.125 & & & \\
\hline SE(m) & 0.006 & 0.088 & & & \\
\hline $\mathrm{CV}$ & 2.509 & 0.454 & & & \\
\hline
\end{tabular}

Strong +++ Medium ++ Low + No production -

Plate.1 PGPR characters of PSB isolates

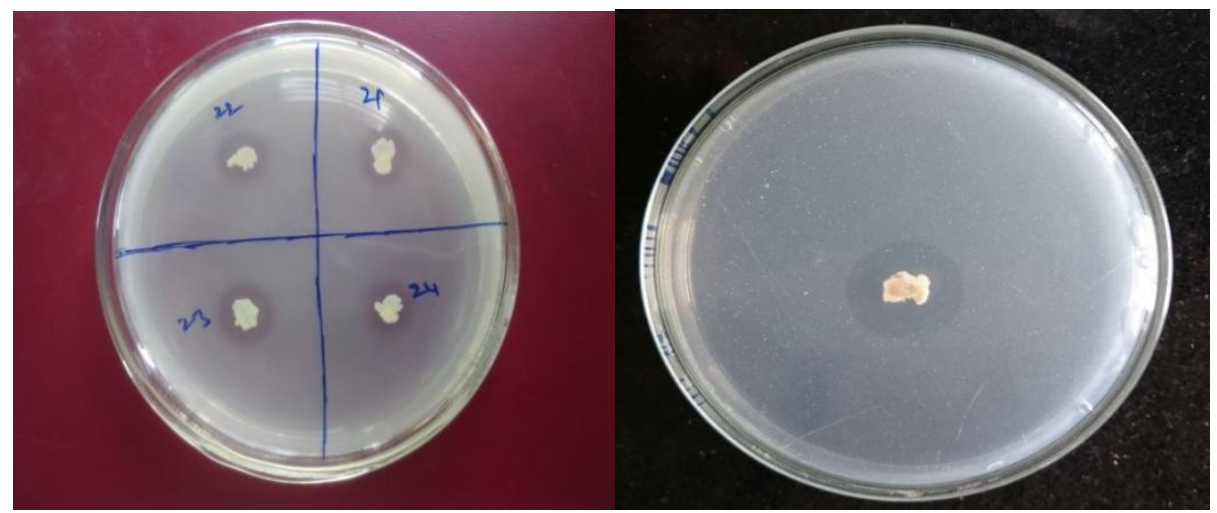

Phosphate solubilization by PSB bacteria
Phosphate solubilization Asp1 fungi 

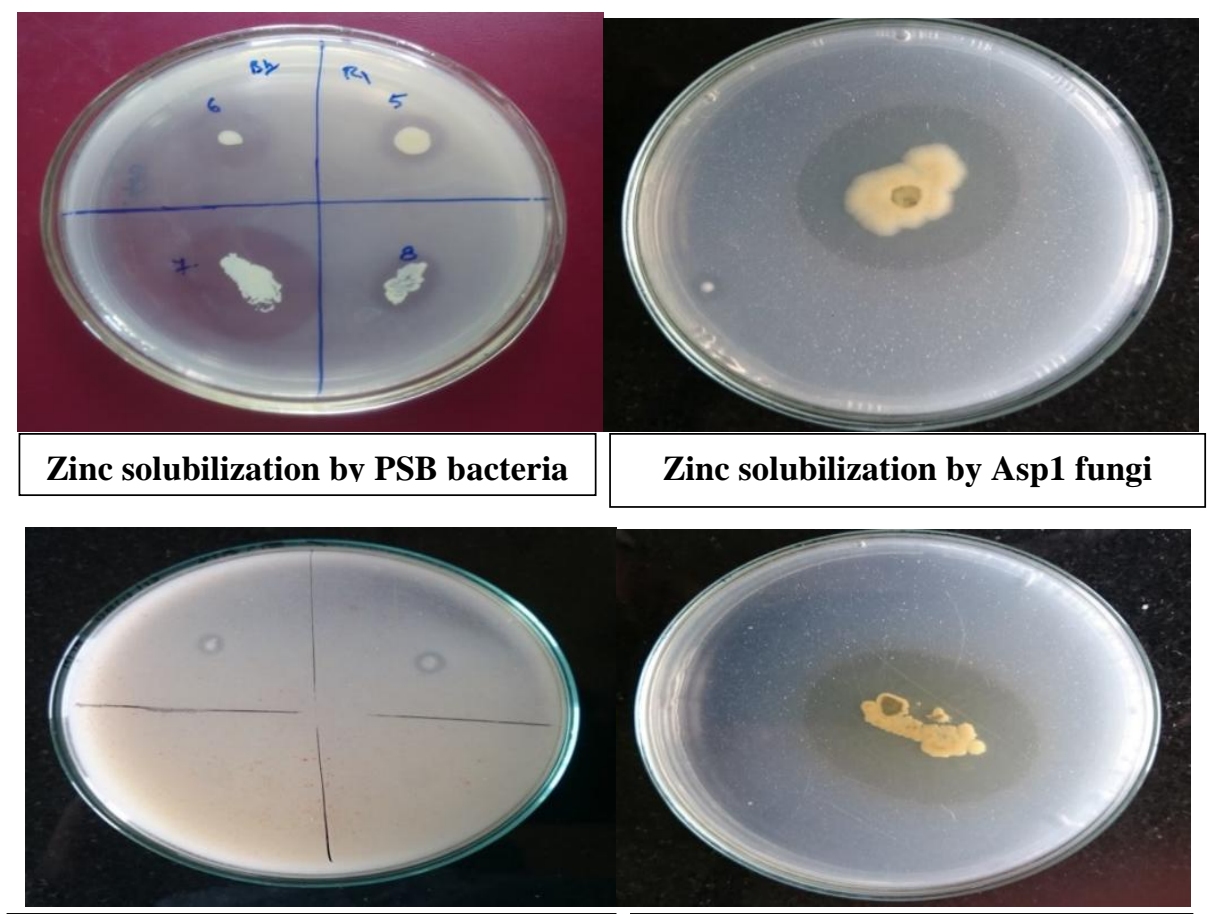

Potassium solubilization by PSB11 bacteria
Potassium solubilization by Asp1 fungi

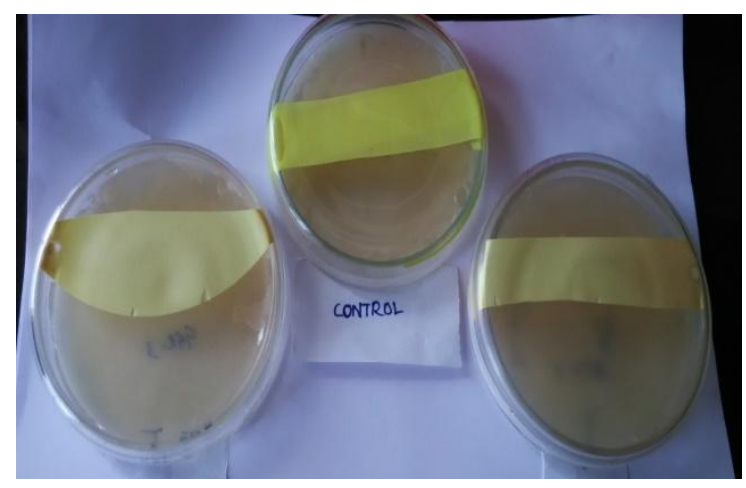

HCN production

Plate.2 PGP activity of PSB isolates

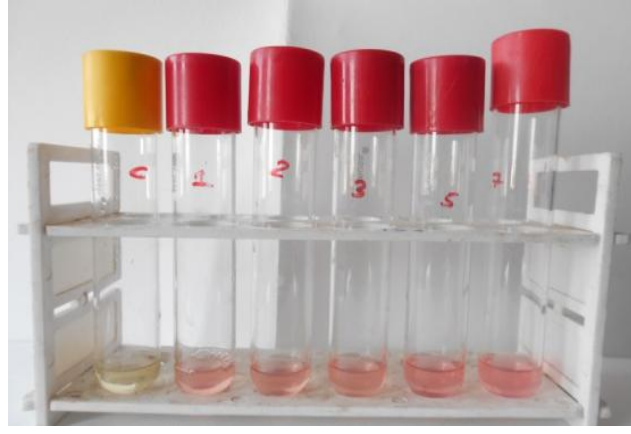

IAA production

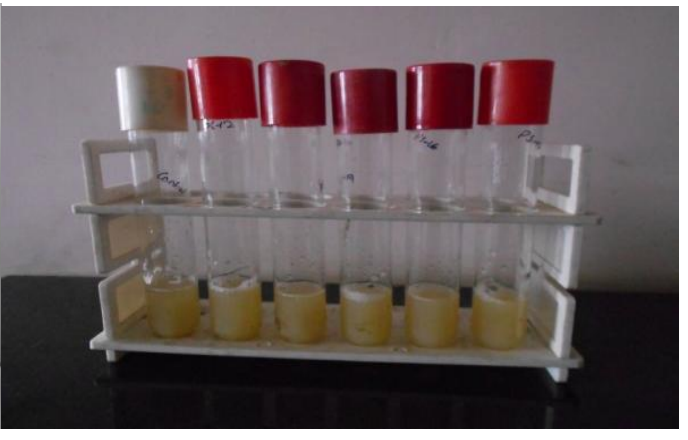

Siderophore production 
The lowest was shown by PSB $3(8.00 \mathrm{~mm})$ and solubilization was not shown by the isolates PSB 2 and PSB 9.

Among eight Pseudomonas isolates, six isolates were able to form clear zone of potassium solubilization on modified Aleksandrov's media ranged from 12.20$6.00 \mathrm{~mm}$. Among them PSB 17 isolate recorded the highest solubilization zone $(12.20 \mathrm{~mm})$ followed by PSB $23(10.00 \mathrm{~mm})$. Least solubilization recorded in PSB 19 (6.00 $\mathrm{mm}$ ). No solubilization was observed in PSB 21 and PSB 24, whereas fungal isolate Aspergillus spp (Asp1) showed $12 \mathrm{~mm}$ Potassium solubilization zone (Table 1 and Plate 1).

The results are agreement with Parmar and Sindhu (2013) who screened one hundred and thirty seven bacterial isolates for the potassium solubilization ability using spot test method on modified Aleksandrov medium plates containing mica powder. They found that out of 137 rhizobacterial isolates tested only 20 formed significant zone of $\mathrm{K}$ solubilization on mica powder containing medium. Out of 20 efficient isolates, 15 (i.e., HWP7, HWP28, HWP38, HWP47, HWP57, HWP63, HWP69, WPS3,CPA123, KPM15, GYB106, WPS73, NNY43, PPM115 and CPA 152) showed more solubilization zone on mica incorporated plates. Five bacterial cultures, namelyHWP15, HWP53, HWP61, CP43 and WPS118 showed small solubilization zone. Three bacterial strains i.e., HWP38, NNY43 and WPS73 showed significant $\mathrm{K}$ solubilization zone.

\section{Exo polysacharide production (EPS)}

Among sixteen Bacillusisolates, fifteen isolates were positive for EPS production; out of which PSB 3showed maximum (+++) EPS production followed by PSB 6 and PSB 13 which showed moderate $(++)$ production then remaining were weak $(+)$ producers and no production was shown by the PSB 10 isolate.

Among eight Pseudomonas isolates, sevenisolates were positive for EPS production; out of which PSB 20 and PSB 24 were strong $(+++)$ EPS producers followed by PSB 19 and PSB 22 showed moderate (++) producers and the remaining isolates were weak (+) producers. No production was observed by PSB 17 isolate, whereas Aspergillus spp (Asp1) was negative for EPS production (Table 2 ).

Similar results were observed by Ashraf et al., (2006) who isolated and identified the EPS producing bacteria associated with the roots of three wheat lines grown in saline and nonsaline soil.

Results indicated the presence of various EPS-producing bacterial genera in unplanted saline and non-saline soil, rhizosphere and rhizoplane of the three wheat lines.

\section{Indole Acetic Acid (IAA) production}

Among sixteen Bacillus isolates, fourteen isolates were positive for IAA production; out of which maximum was shown by PSB 4 $\left(50.70 \mu \mathrm{g} \mathrm{mL}^{-1}\right)$ followed by PSB2 $(41.50 \mu \mathrm{g}$ $\left.\mathrm{mL}^{-1}\right)$, PSB $8\left(40.6 \mu \mathrm{gmL}^{-1}\right)$ and the least was recorded in the isolate PSB $12\left(23.00 \mu \mathrm{gmL}^{-}\right.$ $\left.{ }^{1}\right)$. PSB 5 and PSB 15 were negative for IAA production (Table 2 and Plate 2).

Among eight Pseudomonas isolates, seven isolates were positive for IAA production; out of which maximum was shown by PSB 20 $\left(49.80 \mu \mathrm{gmL}^{-1}\right)$ followed by PSB 24 (34.20 $\left.\mu \mathrm{gmL}^{-1}\right)$, PSB $17\left(32.50 \mu \mathrm{g} \mathrm{mL}^{-1}\right)$ and the least was recorded by the isolate PSB 18 (27.70 $\left.\mathrm{\mu gmL}^{-1}\right)$. PSB 22 was negative for IAA production. Aspergillus spp (Asp1) was positive for IAA production it produced $\left(36.00 \mu \mathrm{g} \mathrm{mL}^{-1}\right)$. 
Hussain and Srinivas (2013) isolated Pseudomonas spp and Azotobacter spp each from rhizosphere of Acacia nilotica and Albizialebbeck and reported that $70 \%$ of the isolates were produced IAA.

Verma et al., (2010) evaluated Rhizobium spp, Pseudomonas fluorescens, Bacillus megaterium and Azotobacter chroococcum for plant growth promoting properties. All the bacterial strains were found to be positive for IAA production and phosphate solubilization.

\section{Protein estimation}

Among the sixteen Bacillus isolates the maximum protein content was recorded in PSB $6\left(0.58 \mathrm{mgmL}^{-1}\right)$ followed by PSB 12 $\left(0.55 \mathrm{mgmL}^{-1}\right)$ and lowest was recorded in PSB 2 and PSB 11 (0.30 $\left.\mathrm{mgmL}^{-1}\right)$. Among the 8 Pseudomonasisolates the maximum protein content was found in PSB $20(0.50$ $\left.\mathrm{mgmL}^{-1}\right)$ followed by PSB $19\left(0.49 \mathrm{mgmL}^{-1}\right)$ and lowest was recorded in PSB $22(0.35$ $\left.\mathrm{mgmL}^{-1}\right)$.Protein content in Aspergillus isolate Asp1was $0.32 \mathrm{mgmL}^{-1}$ (Table 2).

\section{Siderophore production}

Among sixteen Bacillus isolates, thirteen isolates were positive for siderophore production; out of which PSB 6was detected as strong $(+++)$ siderophore producer followed by PSB 1, PSB 3, PSB 5, PSB 10 and PSB 14 showed moderate $(++)$ producers then remaining isolates were weak $(+)$ producers and no production was observed in PSB 2, PSB 9 and PSB 13 isolates.

Among eight Pseudomonas isolates, seven isolates were positive for siderophore production; out of which PSB 17 and PSB 22 were strong $(+++)$ siderophore producers followed by PSB 20 and PSB 23 i.e., moderate $(++)$ producers and the remaining were found to be weak (+) producers. No production was observed in PSB 19.Aspergillus spp (Asp1) was found to be a weak $(+)$ siderophore producer (Table 2 and Plate 2).

The results are similar to the earlier findings of Sreedevi et al., (2014) isolated ten Pseudomonas spp from paddy soil. Among isolated strains three Pseudomonas isolates Pseudomonas 1, Pseudomonas 2 and Pseudomonas 3 showed maximum siderophore production on succinic acid medium and chromo azural $\mathrm{S}$ (single dye) agar medium. Maximum siderophore production was observed in Pseudomonas 1, Pseudomonas 2 and Pseudomonas 3 with 94, 88 and $83 \%$ respectively.

\section{Hydrogen Cyanide (HCN) production}

Among sixteen Bacillus isolates, fifteen isolates were positive for Hydrogen Cyanide production; out of which PSB 10was strong (+++) Hydrogen Cyanide producer followed by PSB 1, PSB 3, PSB 6, PSB 12,PSB 14 and PSB 16 were moderate $(++)$ producers remaining isolates were weak $(+)$ producers and no production was observed in PSB 11 .

Among eight Pseudomonas isolates, six isolates were positive for Hydrogen Cyanide production; out of which PSB 20 was strong $(+++)$ Hydrogen Cyanide producer followed by PSB 21 was moderate $(++)$ producer and the remaining isolates were weak (+) producers. No production was observed in PSB 17 and PSB 24. Aspergillus spp (Asp1) was a weak (+) producer for Hydrogen Cyanide production (Table 2 and Plate 1).

The results are similar to the earlier findings of Jha et al., (2009) who reported production of HCN by some new fluorescent Pseudomonad strains. In the present study $\mathrm{HCN}$ production by PGPR isolates were in agreement with the earlier reports of Punkuj 
and Vishal (2013)on production of plant growth promoting substance by Pseudomonads.

The isolate PSB 6 shows the highest phosphate and zinc solubilisation efficiency (258.33\% and $233.30 \%$ ). The highest protein content also was recorded in PSB 6 i.e., 0.58 $\mathrm{mg} \mathrm{l}^{-1}$.Highestsiderophore production was observed in PSB 6. Based on the above results we concluded that PSB 6 (Bacillus spp) shows more Plant growth promoting characters among 24 isolates.

\section{References}

Ashraf, M., Berge, O., Azam, F and Heulin, T.2006. Bacterial exopolysaccharides and productivity of salt affected soils: Diversity of exopolysaccharideproducing bacteria isolated from the rhizosphere of wheat (Triticum aestivum L.) grown in normal and saline Pakistani soils. Pakistan Journal of Biological Sciences. 2: 201-206.

Barthalomew, J.W., and Mittewer, T. 1950. A simplified bacterial strain. Stain Technology. 25:153.

Castric, K.F., and Castric, P.A. 1983. Method for rapid detection of cyanogenic bacteria. Applied Environmental Microbiology. 45(2): 701-702.

Gaur, A.C., 1990. Phosphate solubilizing microorganisms as biofertilizer. New Delhi: Omega Scientific Publishers.

Gordon, S.A., and weber R.P. 1951. Colorimetric estimation of indole acetic acid. Brief papers: plant physiology. 26: 192-195.

Goteti, P.K., Emmanuel, L.D.A., Desai, S and Shaik, M.H.A. 2013. Prospective zinc solubilising bacteria for enhanced nutrient uptake and growth promotion in maize (Zea mays L.). International Journal of Microbiology. 3: 18-20.
Jha, B.K., Pragash, M.G., Cletus, J., Raman, $\mathrm{G}$ and Sakthivel, N. 2009. Simultaneous phosphate solubilisation potential and antifungal activity of new fluorescent Pseudomonad strains, $P$. aeruginosa, $P$. pelcoglossicida and P. mosselii. World Journal of Microbiological Biotechnology. 25: 573-581.

Karpagam, T., and Nagalakshmi, P. K. 2014. Isolation and characterization of Phosphate Solubilizing Microbes from Agricultural soil. International Journal of Current Microbiology Applied Sciences. 3(3): 601-614.

Lowry, O.H., Rosebrough, N.J., Farr, A.L and Randall, R.J. 1951. Protein measurement with folin-phenol reagent. Journal of Biology and Chemistry.193: 265-275.

Parmar, P., and Sindhu, S.S. 2013. Potassium solubilization by rhizosphere bacteria: influence of nutritional and environmental conditions. Journal of Microbiology Research. 3(1): 25-31.

Prajapati, K.B., and Modi, H.A. 2012. Isolation and characterization of potassium solubilizing bacteria from ceramic industry soil. Journal of microbiology. vol. 1(2-3):pp.8-14.

Punkaj Kumar and Vishal Kumar Deshwal. 2013. Production of Plant growth promoting substance by Pseudomonads. Journal of Academia and Industrial Research (JAIR), 2.

Sandhya, V., Ali, S.K.Z., Minakshi, G., Gopal Reddy and Venkateswarlu, B. 2009. Alleviation of drought stress effects in sunflower seedlings by the exopolysaccharides producing Pseudomonas putida strain GAP-P45. Biology of Fertile Soils. 46: 17-26.

Saravanan, S., Muthumanickam, P., Saravanan, T.S and Santhaguru, K. 2013. Antagonistic potential of fluorescent Pseudomonas and its impact on growth of Tomato challenged with 
phtopathogens. African Crop Science Journal. 21 (1): 29 -36.

Schwyn, B., and Neilands, J.B. 1987. Universal chemical assay for the detection and determination of siderophores. Analytical Biochemistry.160: 47-56.

Seneviratne, G., 2003. Development of ecofriendly, beneficial microbial biofilms. Current Sceince. 85: 1395-1396.

Sreedevi, S.K., Suma, K., Bhuvana, C.A., Prem, K., Minakshi, G., Shankar, M., Maruthi, S., Vanaja, M and Sharma, K.L. 2014. Improving Phytochemical and Nutritional Quality of Spinach (Spinacia oleracea) through Phosphate Solubilizing Bacteria. Indian Journal of Dryland Agriculture Research and Development. 29(2): 104-107.

Tensingh, B.N., and Jemeema, B.P. 2015. Isolation, identification and characterization of phosphate solubilizing bacteria (PSB) isolated from economically important crop plants. International Journal of Current Microbiology and Applied Science, 4(3): 915-924.

Uma Maheswar, N., and Sathiyavani. G. 2012. Solubilization of phosphate by Bacillus spp, from groundnut rhizosphere (Arachis hypogaea L). Journal of Chemical and
Pharmaceutical Research, 4(8): 40074011.

Verma, J.P., Yadav, J and Tiwari, K.N. 2010. Application of Rhizobium spp.BHURCO1 and Plant growth promoting rhizobacteria on nodulation, plant biomass and yields of chickpea (Cicer arietinum L.). International Journal of Agricultural Research. 5(3): 148-156.

Wua, B., Caob, S.C., Lib, Z.H., Cheunga, Z.G and Wonga, K.C. 2005. Effects of biofertilizer containing $\mathrm{N}$-fixer, $\mathrm{P}$ and $\mathrm{K}$ solubilizers and AM fungi on maize growth. Geoderma. 125: 155-162.

Zahir, A., Arshad, Z.M and Frankenberger, W.F. 2004. Plant growth promoting rhizobacteria. Advances in Agronomy. 81: 97-168.

Zaidi, A., and Mohammad, S. 2006. Coinoculation effects of phosphate solubilizing microorganisms and Glomus fasciculatum on green gram bradyrhizobium symbiosis. Agricultural Seience. 30: 223-230.

Zaidi, C.L., Ashford, A.E and Summerell, B.A. 2006. Phosphate solubilising bacteria associated with proteoid roots of seeding of waratah. New Phytologist. 128(3):487-496.

\section{How to cite this article:}

Vinod Babu, S., S. Triveni, R. Subhash Reddy and Sathyanarayana, J. 2017. Screening of Maize Rhizosperic Phosphate Solubilizing Isolates for Plant Growth Promoting Characteristics. Int.J.Curr.Microbiol.App.Sci. 6(10): 2090-2101. doi: https://doi.org/10.20546/ijcmas.2017.610.249 